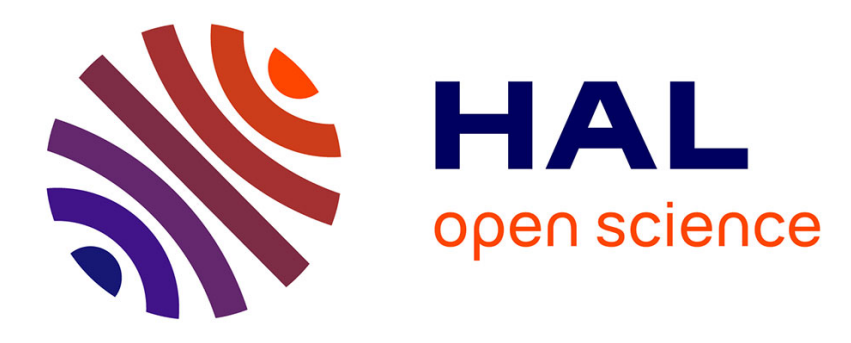

\title{
Influence of root temperature on potassium nutrition of tomato plant
}

\author{
Pierre Cornillon, A. Fellahi
}

\section{To cite this version:}

Pierre Cornillon, A. Fellahi. Influence of root temperature on potassium nutrition of tomato plant.

Optimization of plant nutrition, Kluwer, 1993. hal-02845897

\section{HAL Id: hal-02845897 \\ https://hal.inrae.fr/hal-02845897}

Submitted on 7 Jun 2020

HAL is a multi-disciplinary open access archive for the deposit and dissemination of scientific research documents, whether they are published or not. The documents may come from teaching and research institutions in France or abroad, or from public or private research centers.
L'archive ouverte pluridisciplinaire HAL, est destinée au dépôt et à la diffusion de documents scientifiques de niveau recherche, publiés ou non, émanant des établissements d'enseignement et de recherche français ou étrangers, des laboratoires publics ou privés. 


\title{
Influence of root temperature on potassium nutrition of tomato plant
}

\author{
P. CORNILLON and A. FELLAHI \\ Institut National de la Recherche Agronomique, Station d'Agronomie, Domaine St Paul, F-84143 \\ Montfavet, France
}

Key words: Lycopersicon esculentum Mill., potassium, Q10, root surface, root temperature, tomato

\begin{abstract}
The interaction between root temperature and potassium concentration in nutrient solution has been studied in hydroponic culture on young tomato plant (Lycopersicon esculentum Mill.). These two factors affect plant growth but the potassium absorption only varies according to concentration in nutrient solution. The plants grown for 2 weeks in a nutrient solution maintained at $11^{\circ} \mathrm{C}$ with $0.5 \mathrm{mM} \mathrm{L} \mathrm{L}^{-1}$ of potassium synthesize $6.0 \mathrm{~g}$ of total dry matter with $0.58 \mathrm{~g}$ in roots corresponding to $952 \mathrm{~cm}^{2}$ area; while at $3.0 \mathrm{mM} \mathrm{L} \mathrm{L}^{-1}$, the plant gives $6.1 \mathrm{~g}$ of total dry matter with $0.65 \mathrm{~g}$ in the roots corresponding to $1028 \mathrm{~cm}^{2}$. On the other hand, at $21^{\circ} \mathrm{C}$, we can see the following synthesis: at $0.5 \mathrm{mM}$ of $\mathrm{K}$ ion, 6.43 total dry matter with 0.90 in the roots and $1412 \mathrm{~cm}^{2}$ area and respectively $7.03,0.78$ and $2096 \mathrm{~cm}^{2}$ with $3.0 \mathrm{mM} \mathrm{L} \mathrm{L}^{-1}$ of potassium. These results point out that the root surface are not limiting factors for potassium absorption by young tomato plants during a short period of treatment.
\end{abstract}

\section{Introduction}

Root temperature influences the uptake and metabolism of water and mineral elements. Among the mineral elements essential to plant growth, potassium is a major element, representing 4 to $8 \%$ of the dry weight in plant tissue (Epstein, 1972).

Temperature control is currently a constant source of concern to farmers as they strive for energy savings on crops under shelter (La Malfa, 1990).

Our observations concern the role of substrate temperature and potassium concentration in the nutrient solution on tomato growth. Potassium nutrition is studied over time and cation content of the plant is indicated at the end of the trial.

\section{Materials and methods}

Choice of root temperatures and potassium concentrations

The experimental design is a split-plot device with the temperature as a mean treatment. The temperatures selected, $10^{\circ} \mathrm{C}$ and $20^{\circ} \mathrm{C}$, enable us to obtain slowed growth at $10^{\circ} \mathrm{C}$ and normal growth at $20^{\circ} \mathrm{C}$. The temperature remains constant at root level due to the use of hydroponic culture and aeration using bubbles of compressed air.

Potassium nutrition was differentiated by the potassium content levels, 0.5 and a $3.0 \mathrm{mM}$ potassium per liter, and by the renewal rate for the nutrient solution after 5,4 and 3 days to maintain between 0.5 and $1.0 \mathrm{~L}$ of nutrient solution at the root level of each plant.

The $0.5 \mathrm{~m} M \mathrm{~K}$ ion nutrient solution contains $2.0 \mathrm{~m} M$ of $\mathrm{Ca}\left(\mathrm{NO}_{3}\right)_{2}, 0.5 \mathrm{~m} M$ of $\mathrm{KH}_{2} \mathrm{PO}_{4}$, $1 \mathrm{~m} M$ of $\mathrm{NH}_{4} \mathrm{NO}_{3}$ and $0.5 \mathrm{~m} M$ of $\mathrm{MgSO}_{4}$. The $3.0 \mathrm{mM} \mathrm{K}^{+}$solution is made up of $1.5 \mathrm{mM}$ of $\mathrm{Ca}\left(\mathrm{NO}_{3}\right)_{2}, \quad 3.0 \mathrm{~m} M$ of $\mathrm{KNO}_{3}, \quad 0.5 \mathrm{~m} M$ of $\mathrm{NH}_{4} \mathrm{H}_{2} \mathrm{PO}_{4}$ and $0.5 \mathrm{mM}$ of $\mathrm{MgSO}_{4}$. The necessary trace elements essential to plant growth are added to these solutions.

\section{Crop conditions}

Sowing occured on September 5, the plants were transplanted on September 25 at the two leaf 
stage, one tomato by plastic pot containing $1000 \mathrm{~mL}$ of nutrient solution. The trial was conducted from October 9 to 22 . Nutrient solution samples were taken during this period and plant samples were taken at the end of the trial. The various organs of each plant were quickly separated: root, stem + petiole and laminae. Each plant fraction was washed twice in demineralized water under the tap, dried and weighed.

\section{Analyses}

Cations were analyzed by atomic absorption spectrometry of the nutrient solutions and the plant matter previously put into solution, following the Comité Inter Institut method (CII, 1973).

Root surface was measured by image processing (Cuny, Roudot, 1991).

The variance analysis and the Newman-Keuls test were applied to the analytic data resulting from the 4 treatments and the 2 replications using the STAT-ITCF program.

\section{Results}

\section{Growth}

Table 1 presents the results of the influence of root temperature and potassium concentration on the accumulation of dry matter in the plant. The variance analysis shows an interaction effect between these 2 treatments on the ration shoot/ root.

Temperature acts on the root mass with a positive action of the high temperature which is significant at the 5\% level; while potassium

Table 1. Influence of root temperature $\left(10\right.$ and $\left.20^{\circ} \mathrm{C}\right)$ and potassium concentration $\left(0.5\right.$ and $\left.3.0 \mathrm{mM} \mathrm{L} \mathrm{L}^{-1}\right)$ on dry matter synthesis by tomato plant ( $\mathrm{g} / \mathrm{plant})$

\begin{tabular}{llllll}
\hline & \multicolumn{2}{l}{$10^{\circ} \mathrm{C}$} & & & $20^{\circ} \mathrm{C}$ \\
\cline { 2 - 3 } \cline { 5 - 6 } & 0.5 & 3.0 & & 0.5 & 3.0 \\
\hline Root & 0.58 & 0.61 & & 0.90 & 0.78 \\
Stem + petiole & 2.67 & 2.78 & & 2.28 & 2.83 \\
Laminae & 2.75 & 2.71 & & 3.24 & 3.43 \\
Whole plant & 6.00 & 6.10 & & 6.43 & 7.03 \\
Ratio shoot/root & $9.27 \mathrm{a}$ & $9.01 \mathrm{a}$ & $6.12 \mathrm{~b}$ & $8.01 \mathrm{a}$ \\
\hline
\end{tabular}

solely influences the conductive system: stem and petiole.

The Q10 value varies not only as a function of potassium nutrition, but also- and especiallydepending on the organ under study.

$\begin{array}{lll}Q 10 & 0.5 \mathrm{mMK} \text { ion } & 3.0 \mathrm{mMK} \mathrm{K} \text { ion } \\ \text { Root } & 1.84 & 1.57 \\ \text { Stem + petiole } & 0.87 & 1.08 \\ \text { Laminae } & 1.24 & 1.45 \\ \text { Plant } & 1.13 & 1.29\end{array}$

The influence of temperature on the growth of conductive organs is negligible; maximum influence appears to be on roots with a variation opposite to the other organs. On the whole plant, the Q10 values are very similar.

The root surface measured by image analysis corresponds to strong influence by temperature and potassium.

$\begin{array}{lll}11^{\circ} \mathrm{C} & 0.5 \mathrm{~m} M \mathrm{~K} \text { ion } & 952 \mathrm{~cm}^{2} \\ 11^{\circ} \mathrm{C} & 3.0 \mathrm{~m} M \text { Kion } & 1028 \mathrm{~cm}^{2} \\ 21^{\circ} \mathrm{C} & 0.5 \mathrm{~m} M \text { Kion } & 1412 \mathrm{~cm}^{2} \\ 21^{\circ} \mathrm{C} & 3.0 \mathrm{~m} M \text { Kion } & 2096 \mathrm{~cm}^{2}\end{array}$

But during the trial, even at low potassium concentrations, no symptoms of potassium deficiency were ever apparent.

\section{Potassium uptake}

Figure 1 shows the evolution of potassium consumption in the tomato plants as a function of

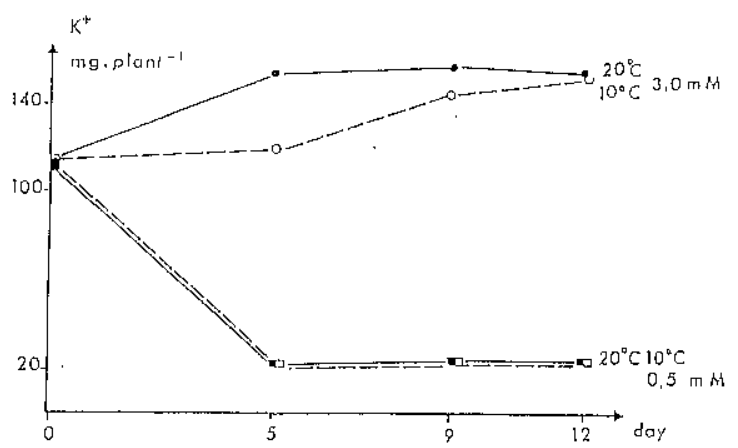

Fig. 1. Influence of root temperature and potassium concentration on potassium uptake by tomato plant (mg/plant/ period). 
the treatment. It is seen that at $0.5 \mathrm{~m} M$, the concentration is the principal limiting factor, whereas at $3.0 \mathrm{~m} M$, temperature limits uptake during the first 9 days of the trial and then it becomes identical at the 2 temperatures. With our experimental design we have also limited the quantity of $\mathrm{K}^{+}$at the root level to obtain a better differenciation of potassium nutrition because you can give large quantity of an element with a low concentration.

The root surface has no influence since the plants absorb the same amount of potassium when the root system surface increases from 50 to 100 percent. Variations in the potassium content of the roots do not seem to play a decisive role in its uptake (Table 2).

When the percentage of potassium is expressed on the dry matter basis in the various organs analyzed, it is seen that it is always a function of the $\mathrm{K}$ ion concentration in the nutrient solution, whereas temperature solely affects concentration in the roots (Table 3 ). It can be noted that there is no correlation between growth and the percentage of potassium in the analyzed organs; proper growth is obtained with low $\mathrm{K}$ ion content in the roots and the laminae.

The transport of potassium between the root and the shoot is not affected by the root zone temperature because the quantities present in the shoot are very similar: $256 \mathrm{mg}^{-1}$ plant $^{-1}$ at $10^{\circ} \mathrm{C}$ and $254 \mathrm{mg}$ plant at $20^{\circ} \mathrm{C}$.

The efficiency of potassium nutrition (mg of dry weight synthesized per $\mathrm{mg}$ of $\mathrm{K}$ ion absorbed) is very high when the nutrient solution contains $0.5 \mathrm{~m} M$ of potassium, whatever the root temperature is (Table 4). Efficiency varies depending on the organ under consideration, however for the stems and the petioles, its value is comparable, at both temperatures, for a given $\mathrm{K}^{+}$concentration.

\section{Calcium and magnesium nutrition}

Table 2 shows the percentages of calcium and

Table 2. Influence of root temperature $\left(10\right.$ and $\left.20^{\circ} \mathrm{C}\right)$ and potassium concentration $\left(0.5\right.$ and $\left.3.0 \mathrm{mM} \mathrm{L} \mathrm{L}^{-1}\right)$ on cation concentration of plant fraction of tomato (\% of dry wt.)

\begin{tabular}{|c|c|c|c|c|c|}
\hline \multirow[t]{2}{*}{ Plant fraction } & \multirow[t]{2}{*}{ Element } & \multicolumn{2}{|l|}{$10^{\circ} \mathrm{C}$} & \multicolumn{2}{|l|}{$20^{\circ} \mathrm{C}$} \\
\hline & & 0.5 & 3.0 & 0.5 & 3.0 \\
\hline \multirow[t]{3}{*}{ Root } & $\mathrm{K}$ & 2.83 & 5.72 & 1.72 & 4.25 \\
\hline & $\mathrm{Ca}$ & 0.75 & 0.66 & 0.71 & 0.70 \\
\hline & $\mathrm{Mg}$ & 0.44 & 0.44 & 0.83 & 0.53 \\
\hline \multirow{3}{*}{$\begin{array}{l}\text { Stem }+ \\
\text { petiole }\end{array}$} & $\mathrm{K}$ & 3.66 & 8.88 & 3.82 & 9.05 \\
\hline & $\mathrm{Ca}$ & 1.59 & 1.68 & 2.84 & 1.82 \\
\hline & $\mathrm{Mg}$ & 0.26 & 0.35 & 0.66 & 0.46 \\
\hline \multirow[t]{3}{*}{ Laminae } & $\mathrm{K}$ & 1.91 & 4.41 & 1.32 & 3.67 \\
\hline & $\mathrm{Ca}$ & 2.51 & 2.99 & 3.15 & 3.00 \\
\hline & $\mathrm{Mg}$ & 0.38 & 0.49 & 0.42 & 0.55 \\
\hline
\end{tabular}

Table 3. Influence of root temperature and potassium concentration on cations concentration of tomato plant fractions (\% of dry wt.) (Treatment rank based on the Newman Keuls test at 5\% confidence interval. The results with the same letter are not different)

\begin{tabular}{|c|c|c|c|c|c|}
\hline \multirow[t]{2}{*}{ Plant fraction } & \multirow[t]{2}{*}{ Element } & \multicolumn{2}{|c|}{$\mathrm{K}^{+}\left(\mathrm{m} M \mathrm{~L}^{-1}\right)$} & \multicolumn{2}{|c|}{ Room temperature } \\
\hline & & 0.5 & 3.0 & $10^{\circ} \mathrm{C}$ & $20^{\circ} \mathrm{C}$ \\
\hline Root & $\mathrm{K}$ & $2.28 \mathrm{~b}$ & $4.97 \mathrm{a}$ & $4.28 \mathrm{a}$ & $2.97 \mathrm{~b}$ \\
\hline \multirow{2}{*}{$\begin{array}{l}\text { Stem }+ \\
\text { petiole }\end{array}$} & $\mathrm{K}$ & $3.74 \mathrm{~b}$ & $8.97 \mathrm{a}$ & & \\
\hline & $\mathrm{Ca}$ & $2.21 \mathrm{a}$ & $1.75 \mathrm{~b}$ & $1.63 \mathrm{~b}$ & $2.33 a$ \\
\hline \multirow[t]{2}{*}{ Laminae } & $\mathrm{K}$ & $1.67 \mathrm{~b}$ & $4.03 \mathrm{a}$ & & \\
\hline & $\mathrm{Mg}$ & $0.40 \mathrm{a}$ & $0.52 \mathrm{a}$ & & \\
\hline
\end{tabular}


magnesium in the various plant organs as a function of the treatments and the Table 3 shows the significance at the $5 \%$ level.

Temperature causes an increase in the calcium and magnesium content in the laminae and in the conductive organs, while at the root level, only magnesium is involved. However, the potassium treatment has no clear influence on calcium and magnesium content in the various organs.

When considering the quantity of calcium and magnesium in the different parts of the plant, it is only the quantities present in the stem and the petiole which vary under the influence of the temperature and of the potassium. The quantities below are expressed in $\mathrm{mg}$ by organ.

\begin{tabular}{lclll} 
Temperature & $10^{\circ} \mathrm{C}$ & \multicolumn{3}{l}{$20^{\circ} \mathrm{C}$} \\
$\mathrm{K}^{+}$concentration & $0.5 \mathrm{~m} M$ & $3.0 \mathrm{~m} M$ & $0.5 \mathrm{~m} M$ & $3.0 \mathrm{~m} M$ \\
$\mathrm{Ca}^{2+}$ & 42.4 & 46.6 & 64.8 & 51.5 \\
$\mathrm{Mg}^{2+}$ & 6.92 & 9.71 & 15.0 & 13.1
\end{tabular}

At $10^{\circ} \mathrm{C}$, the quantity of $\mathrm{Ca}^{2+}$ and $\mathrm{Mg}^{2+}$ increases which the concentration of $\mathrm{K}^{+}$, while at $20^{\circ} \mathrm{C}$, we observe the reverse phenomenon. However, the quantity in the conductive tissues is always higher at $20^{\circ} \mathrm{C}$ than at $10^{\circ} \mathrm{C}$.

\section{Discussion}

Many authors have observed a reduction in potassium, calcium and magnesium content in plant tissue when growth occurs at a low temperature, compared to plants grown at normal temperatures (Kafkafi, 1990; Tindall et al., 1990). According to Bingham and Cumbus (1991), these observations depend on the reference used: dry weight or fresh weight, especially for potassium.

In fact, our results, with the $\mathrm{K}^{+}$content expressed on dry matter weight, show that normal growth is obtained with lower potassium levels in the roots and the laminae, whereas the level is slightly higher in the stems and petioles. Plant's potassium nutrition is shown more conclusively by checking potassium content in the conductive tissue: stem and petiole.

The absorption of potassium is independent of root temperature during the 12 days of observation and this result supports the observations on barley of Siddiqi et al. (1984) who has studied the same temperature during short periods. Engels et al. (1992) have noted a marqued influence of root zone temperature on nitrogen, potassium and calcium uptake by maize grown in water culture."

Unlike the results obtained by Bingham and Cumbus (1991), we have not observed any stable concentration of $\mathrm{K}^{+}$in the tissues at $10^{\circ} \mathrm{C}$ and at $20^{\circ} \mathrm{C}$ when potassium nutrition is near optimal. Indeed, the difference is felt when expressing the results as a function of the water content in the tissues since at low temperatures, there is greater dry weight due to the accummulation of soluble solids and starch in the cells and to the thickening of the pecto-cellulosic walls (Cornillon, 1974). At $12^{\circ} \mathrm{C}$, there are accumulations of total dry matter in the roots, especially carbohydrates and also organic nitrogen.

Plants' response to variations in root temperature depends on the species.

In our experiment, the transport of potassium between root and shoot is not affected by root zone temperature unlike Engels et al. (1992) findings. These authors have observed an increased translocation of $\mathrm{K}^{+}, \mathrm{N}$ and $\mathrm{Ca}^{++}$from root to shoot after 3,5 and 10 days treatment.

Efficient use of potassium occurs when the substrate is very poor in the element at the two temperatures, however such efficiency decreases when the supply of potassium is higher with a better plant growth (Table 4).

At low root temperature, the flow of sap within the plant undergoes changes in speed, with, in particular, a decrease at the collar level and in the roots. These variations can cause an increase in its needs for $\mathrm{K}$ ion to insure solution transfer and to meet its role of osmoticum in the

Table 4. Indices of efficiency of potassium (mg DM/mg K $\mathrm{K}^{+}$ absorbed) for plants at 2 potassium concentration in solution (Treatment rank based on the Newman Keuls test at $5 \%$ confidence interval)

\begin{tabular}{lll}
\hline $\mathrm{K}^{+}\left(\mathrm{m} M \mathrm{~L}^{-1}\right)$ & $\mathrm{K}^{+}\left(\mathrm{m} M \mathrm{~L}^{-1}\right)$ & \\
\cline { 2 - 3 } & 0.5 & 3.0 \\
\hline Root & $47.13 \mathrm{a}$ & $20.58 \mathrm{~b}$ \\
Stem + petiole & $27.40 \mathrm{a}$ & $11.15 \mathrm{~b}$ \\
Laminae & $65.60 \mathrm{a}$ & $25.08 \mathrm{~b}$ \\
Plant & $40.88 \mathrm{a}$ & $16.13 \mathrm{~b}$ \\
\hline
\end{tabular}


cells. Our results highlight the correlation between potassium nutrition and synthesis of conductive tissue.

In conclusion, it appears that tomato growth is not greatly affected even if there are great variations in the concentration of potassium in the substrate, when root temperature is favorable. This normal growth corresponds to highly varied levels of potassium in the plant organs. Root surface is not a limiting factor in potassium nutrition since the same quantity of potassium is absorbed by plants having very different root systems. The lowest growth, noted at $10^{\circ} \mathrm{C}$, cannot be linked to potassium deficiency since tissue content corresponds to the range of standard values.

\section{References}

Bingham I J and Cumbus I P 1991 Influence of root temperature on the potassium requirement of young tomato plants. Plant and Soil 133, 227-237.
C I I 1972 Méthodes de référence pour la détermination des éléments minéraux dans les végétaux. Oléagineux $28,87-$ 92.

Cornillon P 1977 Influence de la température du substrat sur la composition des racines et des limbes de tomate. Implications concernant l'absorption hydrique. Ann. Agron. 28, 277-289.

Cuny $\mathrm{F}$ and Roudot A C 1991 Germination et croissance pollinique in vitro du pollen de melon (Cucumis melo L.) après irradiation gamma. Envir. Exp. Bot. 31, 277-283.

Engels C, Munkle L and Marschner H 1992 Effect of root zone temperature and shoot demand on uptake and xylem transport of macronutrients in maize (Zea mays L.) J. Exp. Bot. 43, 537-547.

Epstein E 1972 Mineral Nutrition of Plants: Principles and Perspectives. Wiley, New York, 412 p.

Kafkafi V 1990 Root temperature, concentration and the ratio $\mathrm{NO}_{3}^{-} / \mathrm{NH}_{4}^{+}$effect on plant development. J. Plant Nutr. 13, 1291-1306

La Malfa G 1990 Melanzana. In Orticultura. Eds. V V Bianco and F Pimpini Coordinatore. pp 793-811. Patron Editore Bologna.

Siddiqi M Y, Memon A R and Glass A D M 1984 Regulation of $\mathrm{K}^{+}$influx in barley; effect of low temperature. Plant Physiol. 74, 730-734.

Tindall J A, Mills H A and Radcliffe D E 1990 The effect of root zone temperature on nutrient uptake of tomato. J. Plant Nutr. 13, 939-956. 